\title{
Digestible lysine for 63 to 103 day-old barrows of genetic lines selected for lean deposition
}

\author{
Eduardo lanino Fortes ${ }^{1}$, Juarez Lopes Donzele ${ }^{2}$, Rita Flávia Miranda de Oliveira ${ }^{2}$, Alysson \\ Saraiva ${ }^{1}$, Francisco Carlos de Oliveira Silva ${ }^{3}$, Matheus Faria de Souza ${ }^{1}$, Gabriel Cipriano \\ Rocha $^{1}$, Leandro Alebrante ${ }^{1}$
}

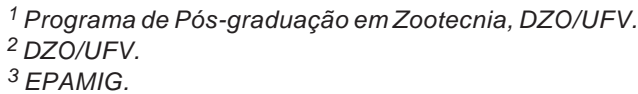

\begin{abstract}
Ninety-six barrows from 63 to 103 days of age were used to evaluate the effects of dietary digestible lysine levels on performance and carcass traits of two genetic lines selected for lean deposition. Pigs with initial body weight of $23.800 \pm 1.075 \mathrm{~kg}$ were allotted in a completely randomized block design, within a $4 \times 2$ factorial arrangement (four digestible lysine levels: $0.80,0.90,1.00,1.10 \%$, and two genetic lines), with six replicates and two pigs per experimental unit. There was no interaction between genetic and digestible lysine levels. The digestible lysine levels also did not influence performance or carcass traits of pigs; however, average daily lysine intake increased with increasing digestible lysine level in the experimental diets. Pigs from genetic line B had better carcass traits when compared with those from genetic line A. The level of $0.80 \%$ digestible lysine corresponding to a daily intake of $16.60 \mathrm{~g}$ digestible lysine meets the nutritional requirement of pigs from both genetic lines evaluated, from 63 to 103 days of age.
\end{abstract}

Key Words: amino acids, carcass, genotype, growing, performance

\section{Introduction}

Values of amino acids' digestibility must be taken into account in the formulation of pigs' diet to reduce costs and maximize animals' performance. Thus, studies to determine the digestible amino acid requirements of pigs at specific stages of production are essential to allow optimal expression of their genetic potential for meat deposition.

Lysine is the first limiting amino acid in corn and soybean meal based diets for pigs, and is also one of the main nutrients directly responsible for muscle deposition, due to its constancy in body protein and destination primarily to the deposition of lean tissue. Therefore, the responses of performance and lean gain of pigs may be associated with the level of lysine in the diet (Oliveira et al., 2003).

In experiments to determine the requirement of digestible lysine, it is essential to consider the ratios of the essential amino acids with lysine in the diets to avoid variations in the pigs' performance. When the level of supplementation of an essential amino acid is inadequate, performance may be limited by the amino acid that is deficient in the diet, although the level of dietary lysine is adequate.
As genetic companies constantly offer new strains of pigs with high capacity for meat production, research is needed to determine the digestible lysine requirements of these new strains or performance may be compromised.

Thus, this study was conducted to evaluate levels of digestible lysine in diets for barrows 63 to 103 days of age from two genetic lines selected for meat deposition.

\section{Material and Methods}

The experiment was conducted at the Setor de Suinocultura in Departamento de Zootecnia, Universidade Federal de Viçosa, Viçosa, Minas Gerais, during March and April of 2007.

Ninety-six barrows (48 line A and 48 line B) were selected for meat deposition, with initial body weight of $23.800 \pm 1,075 \mathrm{~kg}$, allotted in a completely randomized block design, within a $4 \times 2$ factorial arrangement (four digestible lysine levels and two genetic lines), with six replications and three pigs per experimental unit. Body weight and genetic line were considered as criterion in the blocks formation.

Pigs were housed in pens of $3 \mathrm{~m}^{2}$, equipped with semiautomatic feeders and drinkers, located in a concrete floor facility, covered with ceramic tiles. 
Experimental diets (Table 1) were formulated to meet the nutritional requirements of pigs in the growth phase, according to the nutritional recommendations of Rostagno et al. (2005), except for digestible lysine. The treatments corresponded to the levels of $0.80,0.90,1.00$, and $1.10 \%$ digestible lysine, obtained from a basal diet supplemented with L-lysine $\mathrm{HCl}$ replacing starch.

In all diets, the ratios between the digestible amino acids and lysine were checked to ensure that no essential amino acid was deficient. In the evaluation of amino acid ratios with lysine, those recommended by Rostagno et al. (2005) in the ideal protein were used.

Diets and water were supplied ad libitum to pigs throughout the experimental period (63 to 103 days of age). Diets, leftovers and waste were weighed weekly, and pigs were weighed at the beginning and at the end of the experimental period to determine weight gain, feed intake, digestible lysine intake and feed conversion.

At the end of the experiment, to evaluate loin-eye area (LEA) and backfat thickness (BF) of pigs, an ultrasonic apparatus (Aloka SSD 500) was used, and measurements were taken between the tenth and eleventh ribs. AOL and ET were later calculated using the computer program AUSKey System V-5.0. The amount of meat in the carcass was obtained from the formula proposed by Cline et al. (2000):

Meat $(\mathrm{kg})=9.77+(0.343 \times$ hot carcass weight, $\mathrm{kg})-$ $(0.291 \times \mathrm{BF} \mathrm{mm})$

The performance variables (weight gain, feed intake, digestible lysine intake and feed conversion) and carcass traits (loin-eye area, backfat thickness and amount of meat) were analyzed using the procedures for analysis of variance and regression contained in the Sistema para Análises Estatísticas e Genéticas (SAEG), developed at Universidade Federal de Viçosa (UFV, 2000), version 9.0.

\section{Results and Discussion}

There was no interaction $(\mathrm{P}>0.05)$ between lysine levels and genetic lines for performance and carcass traits.

Regardless of genetic lines, the levels of lysine did not influence $(\mathrm{P}>0.05)$ average daily weight gain (ADG) of pigs (Table 2), this result is similar to those obtained by Owen et al. (1994), Gomes et al. (2000) and Abreu et al. (2007), who assessed levels of 0.80 to $1.15 \%$ digestible lysine for growing barrows and also found no effect of treatments in the growth rate of pigs.

Table 1 - Percentage and calculated composition of experimental diets

\begin{tabular}{|c|c|c|c|c|}
\hline \multirow[t]{2}{*}{ Ingredient } & \multicolumn{4}{|c|}{ Digestible lysine levels (\%) } \\
\hline & 0.80 & 0.90 & 1.00 & 1.10 \\
\hline Corn & 67.300 & 67.300 & 67.300 & 67.300 \\
\hline Nucleous $^{1}$ & 4.000 & 4.000 & 4.000 & 4.000 \\
\hline Soybean oil & 0.870 & 0.870 & 0.870 & 0.870 \\
\hline Starch & 1.170 & 1.008 & 0.738 & 0.433 \\
\hline L-lysine $\mathrm{HCl}$ & 0.000 & 0.129 & 0.259 & 0.387 \\
\hline DL-methionine & 0.000 & 0.025 & 0.088 & 0.150 \\
\hline L-threonine & 0.000 & 0.008 & 0.081 & 0.153 \\
\hline L-tryptophan & 0.000 & 0.000 & 0.004 & 0.023 \\
\hline L-valine & 0.000 & 0.000 & 0.000 & 0.024 \\
\hline Total & 100.00 & 100.00 & 100.00 & 100.00 \\
\hline \multicolumn{5}{|c|}{ Calculated nutritional composition ${ }^{2}$} \\
\hline Digestible tryptophan (\%) & 0.187 & 0.187 & 0.191 & 0.210 \\
\hline Digestible threonine (\%) & 0.587 & 0.595 & 0.661 & 0.726 \\
\hline Digestible met + cys (\%) & 0.524 & 0.549 & 0.610 & 0.671 \\
\hline Digestible isoleucine (\%) & 0.668 & 0.668 & 0.668 & 0.668 \\
\hline Digestible valine (\%) & 0.746 & 0.746 & 0.746 & 0.770 \\
\hline Calcium (\%) & 0.665 & 0.665 & 0.665 & 0.665 \\
\hline Available phosphorus (\%) & 0.340 & 0.340 & 0.340 & 0.340 \\
\hline
\end{tabular}


Table 2 - Performance and carcass traits of barrows from two genetic lines fed on diets containing four digestible lysine levels

\begin{tabular}{|c|c|c|c|c|c|c|c|}
\hline \multirow[t]{2}{*}{ Variable $^{1}$} & \multicolumn{4}{|c|}{ Digestible lysine level (\%) } & \multicolumn{2}{|c|}{ Line } & \multirow[t]{2}{*}{ CV $(\%)$} \\
\hline & 0.80 & 0.90 & 1.00 & 1.10 & A & B & \\
\hline Initial weight (kg) & 23.9 & 23.7 & 23.8 & 23.7 & 24 & 23.5 & 2.31 \\
\hline Final weight (kg) & 61.7 & 61.9 & 61.6 & 61.9 & 62.4 & 61.1 & 4.43 \\
\hline ADG (g) & 944 & 956 & 946 & 954 & 962 & 938 & 7.00 \\
\hline ADFI (g) & 2077 & 2065 & 2078 & 2110 & 2112 & 2052 & 6.80 \\
\hline$F: G$ & 2.20 & 2.16 & 2.20 & 2.21 & 2.20 & 2.19 & 4.71 \\
\hline $\mathrm{ADLI}^{2}$ & 16.6 & 18.6 & 20.8 & 22.0 & 20.0 & 19.4 & 6.07 \\
\hline LEA & 23.3 & 23.6 & 23.0 & 23.6 & $22.5 b$ & $24.25 a$ & 9.24 \\
\hline $\mathrm{BF}(\mathrm{mm})$ & 13.1 & 13.5 & 14.2 & 12.0 & $14.4 \mathrm{a}$ & $12.1 \mathrm{~b}$ & 21.67 \\
\hline Amount of meat $(\mathrm{kg})$ & 22.1 & 22.0 & 21.8 & 22.6 & $21.7 \mathrm{~b}$ & $22.6 a$ & 4.72 \\
\hline
\end{tabular}

On the other hand, Fontes et al. (2005), testing lysine levels $(0.80,0.90,1.00$, and $1.20 \%)$ in diet for 30 to $60 \mathrm{~kg}$ gilts found a linear increase in ADG. Similarly, Souza et al. (2008) in a study with female and castrated male pigs from 60 to 95 days of age assessed dietary lysine levels ranging from 0.85 to $1.15 \%$ and found a linear effect of the lysine levels in the ADG of pigs.

The ADG of $950 \mathrm{~g}$ obtained in this study was similar to the values 944 and $951 \mathrm{~g}$ found by Owen et al. (1994) and Fontes et al. (2000), respectively, and higher than the values of 910, 893 and 757 obtained by Fontes et al. (2005), Haese et al. (2006) and Souza et al. (2008). Besides ambient temperature and pigs' health standard (Williams et al., 1997; LeFloc'h et al., 2004; Trevisi et al., 2009), the inconsistency in the response of ADG in relation to the digestible lysine levels in the diets verified among studies may be due to differences in the genetic potential of pigs for lean gain. According to Stahly et al. (1994), the intensity of ADG response related to the lysine concentration in the diet depends on the genetic potential of pigs.

Confirming these propositions, Gasparoto et al. (2001), in a study to evaluate lysine requirements of pigs from different genetic groups concerning their growth potential, found that the response of ADG to the levels of lysine varied according to the genetics.

According to Yen et al. (1986), the responses of performance and carcass meat deposition in pigs may be associated with the level of dietary lysine due to the requirement in a larger quantity of this amino acid for protein deposition and its high concentration in muscle tissues. Based on these considerations, the fact that in this study pigs of different genetic lines have shown similar ( $P>0.05$ ) values of ADG may have contributed to the absence of effect in the lysine requirements among them.

There was no effect $(\mathrm{P}>0.05)$ of the lysine levels on average daily feed intake (ADFI) nor variation $(\mathrm{P}>0.05)$ in this parameter between pigs of different genetic lines, showing that feed intake capacity was not a significant variable to differentiate the two lines.

In a similar way, Donzele et al. (1994), Fontes et al. (2000), Gasparoto et al. (2001), Abreu et al. (2007), Souza et al. (2008) and Fisher et al. (2009) also found no effect of dietary lysine levels on feed intake of growing pigs.

The consistency of results among studies with respect to the effects of lysine level in ADFI is an indication that pigs do not adjust their voluntary intake to meet lysine requirements, contrary to what occurs in the case of tryptophan (Ettle \& Ruth, 2004). This proposition is consistent with the data of Owen et al. (1994), who evaluating diets with different lysine concentrations $(0.50,1.1$, and $1.60 \%$ ) fed in the system of free choice found that pigs were not able to regulate their intake due to the lysine concentration in the diets. In the same sense, Edmonds \& Baker (1987) stated that excess of lysine and other amino acids did not influence feed intake by pigs. On the other hand, according to Kerr et al. (2003), the imbalance of amino acids in the diet may result in changes in pigs' voluntary consumption. However, in this study, there was no amino acid imbalance as diets were supplemented with industrial amino acids, maintaining the ratios with lysine.

There was effect $(\mathrm{P}<0.05)$ of lysine levels in the average daily lysine intake (ADLI), which increased linearly according to the equation: $\hat{Y}=0.4802+21.2818 X\left(r^{2}=0.99\right)$. Several authors, among them, Friesen et al. (1994), Fontes et al. (2000, 2005), Gasparoto et al. (2007), and Abreu et al. (2007) also found a linear increase in lysine intake due to its increasing levels in the diets. The fact that the ADFI of pigs did not vary among lysine levels justifies the direct relationship between the daily intake of lysine and its concentration in the diet.

There was no effect $(\mathrm{P}>0.05)$ of lysine level on feed conversion (FC) of pigs (Table 2). These results are 
consistent with those obtained by Gasparoto et al. (2001) and Haese et al. (2006), who found no variation in the feed efficiency for weight gain when evaluating lysine levels for growing barrows. In contrast, conducting studies to evaluate levels of lysine for growing pigs, Friesen et al. (1994), Smith et al. (1999), Fontes et al. (2000), Abreu et al. (2007) and Souza et al. (2008) observed significant variation in pigs' feed conversion.

The divergence of results between studies may be related to differences in the genetics of pigs used concerning the capacity of protein deposition in the carcass. According to Campbell \& Taverner (1998), the selection of pigs to improve feed efficiency has resulted in animals with higher potential for meat gain.

There was no difference $(\mathrm{P}>0.05)$ in feed conversion of pigs from the different lines evaluated in this study. Based on these data, one can infer that although genetically different, pigs showed a similar capacity for growth and feed efficiency, thus justifying the fact that no significant interaction occurred between the levels of lysine and the genetic groups of pigs.

In the evaluation of carcass traits, there was no effect ( $\mathrm{P}>0.05)$ of lysine levelson loin-eye area (LEA) nor on the amount of meat (AM) in the carcasses. These results are similar to those obtained by Smith et al. (1999), who evaluated the effect of lysine with calorie in the diets on the performance and carcass traits of for growing-finishing pigs, and found no effect on loin depth. Similarly, Power et al, (2000) also found no effect of lysine levels on protein deposition in the carcasses of growing gilts.

In contrast, in a study conducted with growing pigs, Friesen et al. (1994) verified significant variation in the values of loin-eye area due to the increased levels of lysine. In the same way, Abreu et al. (2007) found significant effect of lysine levels on carcass protein deposition in castrated male pigs from 30 to $60 \mathrm{~kg}$.

The differences in the results between studies are probably related, among other factors, to differences in pigs' genetics. Assessing the lysine requirement of barrows from two genetic groups in the growth phase, Gasparoto et al. (2001) found that the effect of lysine level in loin depth (LD) varied according to the genetics of pigs.

Although there was no interaction between the levels of lysine and genetic lines, pigs from line B had higher $(\mathrm{P}<0.05)$ values of LEA and amount of meat in the carcass compared with those of line A. However, the increases corresponding to $7.70 \%$ and $4.20 \%$ for LEA and amount of meat in the carcass of pigs from line B, respectively, were not sufficient to alter performance concerning growth rate and feed efficiency. Likewise, no change was observed $(\mathrm{P}<0.05)$ in backfat thickness $(\mathrm{BF})$ of pigs with increasing lysine levels, a fact also observed by Gasparotto et al. (2001), who, assessing lysine levels for barrows from two genetic groups in the growth phase, found no effect of treatments in backfat thickness measured at the $\mathrm{P}_{2}$, regardless of the genetics of pigs. The values obtained are similar to those of Friesen et al. (1994), who observed no significant variation in the values of backfat thickness of pigs due to increased levels of lysine. More recently, Abreu et al. (2007) also found no variation in the percentage or amount of fat deposition in the carcass of barrows from 30 to $60 \mathrm{~kg}$ increasing the concentration of dietary lysine.

In contrast with this result, Fontes et al. (2005) observed a reduction in the percentage and amount of fat in the carcass of growing gilts associated with the increase of lysine in the diet. The results of the effects of dietary lysine concentration in the amount of fat in the carcass are not consistent and indicate that this variable is not adequate to establish the requirements of pigs.

The best results for LEA and the amount of meat in the carcass of pigs from line $B$ are compatible with the lower $(\mathrm{P}<0.05)$ backfat thickness value of this line. The fact that the line $\mathrm{B}$ pigs have shown lower value of $\mathrm{BF}$, but equal ADG value in relation to line A pigs, is consistent with the results of Van Lunem \& Coli (1996), who found that by increasing the lysine:energy relation of the diet results in reduction of backfat thickness, with no change in the rate of pigs' growth.

The results of carcass traits evaluated in this study are similar to those obtained by Unruh et al. (1996), who evaluated the influence of genotype, sex and lysine levels on carcass quality of pigs and concluded that lysine had minimal effect on carcass traits.

The level of $0.80 \%$ digestible lysine, corresponding to a daily intake of $16.6 \mathrm{~g}$, meets the requirements of pigs of the two genetics lines for performance and carcass traits, characterizing the pigs used in this study as having average genetic potential for meat deposition in the carcass, according to information by Rostagno et al. (2005), which sets the digestible lysine requirement at $16.19 \mathrm{~g}$, for this category of pigs.

\section{Conclusions}

The level of $0.80 \%$ digestible lysine, corresponding to a daily intake of $16.60 \mathrm{~g}$, meets the nutritional requirements of barrows selected for lean deposition in the phase of 63 to 103 days of age. 


\section{References}

ABREU M.L.T.; DONZELE J.L.; OLIVEIRA R.F.M. Níveis de lisina digestível em rações, utilizando-se o conceito de proteína ideal, para suínos machos castrados de alto potencial genético, dos 30 aos $60 \mathrm{~kg}$. Revista Brasileira de Zootecnia, v.36, p.62-67, 2007.

CAMPBELL, R.G.; TAVERNER, M.R. Genotype and sex on the relationship between energy and protein deposition in growing pigs. Journal of Animal Science, v.66, p.676-686, 1988.

CLINE, T.R.; CROMWELL, G.L.; CRENSHAW, T.D. Further assessment of the dietary lysine requirement of finishing gilts. Journal of Animal Science, v.78, p.987-992, 2000.

DONZELE, J.L.; FREITAS, R.T.F.; OLIVEIRA, R.F.M. et. al. Níveis de lisina para leitoas de 30 a $60 \mathrm{~kg}$ de peso vivo. Revista da Sociedade Brasileira de Zootecnia, v.24, p.967-973, 1994.

EDMONDS, M.S.; BAKER, D.H. Aminoacids excesses for young pigs: Effects of excess methionine, tryptophan, threonine or leucine. Journal of Animal Science, v.64, p.1664-1671, 1987.

ETTLE, T.; RUTH, F.X. Specific dietary selection for tryptophan by the piglet. Journal of Animal Science, v.82, p.1115-1121, 2004.

FISCHER, M.; HIRCHE, F.; KLUGE, H. et al. A moderate excess of dietary lisine lowers plasma and tissue carnitine concentrations in pigs. British Journal of Nutrition, v.101, p.190-196, 2009.

FONTES, D.O.; DONZELE, J.L.; OLIVEIRA, R.F.M. et al. Níveis de lisina para leitoas selecionadas geneticamente para deposição de carne magra, dos 30 aos $60 \mathrm{~kg}$, mantendo constante a relação entre lisina e metionina + cistina, treonina, triptofano, isoleucina e valina. Revista Brasileira de Zootecnia, v.29, p.776-783, 2000.

FONTES, D.O.; DONZELE, J.L.; OLIVEIRA, R.F.M. et al. Níveis de lisina para leitoas selecionadas geneticamente para deposição de carne magra na carcaça, dos 30 aos 60 kg. Revista Brasileira de Zootecnia, v.34, p.81-89, 2005.

FRIESEN, K.G.; NELSSEN, J.L.; GOODBAND, M.D. Influence of dietary lysine on growth and carcass composition of highlean-growth gilts fed from 34 to 72 kilograms. Journal of Animal Science, v.72, p.1761-1770, 1994.

GASPAROTTO, L.F.; MOREIRA, I.; FURLAN, C.A. Exigência de lisina, com base no conceito de proteína ideal, para suínos machos castrados de dois grupos genéticos, na fase de crescimento. Revista Brasileira de Zootecnia, v.30, p.1742-1749, 2001

GOMES, F.E.; FIALHO, E.T.; LIMA, J.A.F. Planos de nutrição baseados nos níveis de lisina para suínos de diferentes genótipos abatidos aos 80 e $100 \mathrm{~kg}$ de peso vivo. Ciência Agrotecnica, v.24, p.479-489, 2000.

HAESE, D.; SARAIVA, A.; DONZELE, J.L. Exigência de lisina digestível para suínos machos castrados mestiços de duas linhagens comerciais dos 60 aos 100 dias de idade. In: PORK EXPO E CONGRESSO LATINO AMERICANO DE SUinOCUltura, 3., 2006, Foz do Iguaçu. Anais... Foz do Iguaçu, 2006. p.697-699.
KERR, B.J.; YEN, J.T.; NIENABER, J.A. et al. Influence of dietary protein level, amino acid supplementation and environmental temperature on performance, body composition, organ weights and total heat production of growing pigs. Journal of Animal Science, v.81, p.1998-2007, 2003.

LE FLOC'H, N.; MELCHIOR, D.; OBLED, C. Modifications of protein and amino acid metabolism during inflammation and immune system activation. Livestock Production Science, v.87, p.37-45, 2004.

OLIVEIRA, A.L.S.; DONZELE, J.L.; OLIVEIRA, R.F.M. et al. Lisina em rações para suínos machos castrados selecionados para deposição de carne na carcaça dos 95 aos 110 kg. Revista Brasileira de Zootecnia, v.32, p.337-343, 2003.

OWEN, K.Q.; KNABE, D.A.; BURGOON, K.G. Self-selection of diets and lysine requirements of growing-finishing swine. Journal of Animal Science, v.72 p.554-564, 1994.

ROSTAGNO, H.S.; ALBINO, L.F.T.; DONZELE, J.L. et al, Composição de alimentos e exigências nutricionais de aves e suínos: tabelas Brasileiras. Viçosa, MG: UFV, 2005. $186 \mathrm{p}$.

SMITH, J.W.; TOKACH, M.D.; O’QUINN, P.R. et al. Effects of dietary energy density and lysine:calory ratio on growth performance and carcass caracteristics of growing-finishing pigs. Journal of Animal Science, v.77, p.3007-3015, 1999.

SOUZA, L.P.O.; FONTES, D.O.; ROSA, B.O. et al. Níveis de lisina digestível para suínos machos castrados de alto potencial genético para deposição de carne magra de 60 a 95 dias de idade. In: PORK EXPO E SIMPÓSIO INTERNACIONAL DE SUINOCUlTURA, 4., 2008, Cutitiba. Anais... Curitiba, 2008. p.88-89.

STAHLY, T.S.; WILLIAMNS, N.H.; SWENSON, S. Impact of genotype and dietary regimen on growth of pigs from 6 to $25 \mathrm{~kg}$. Journal of Animal Science, p.72-165, 1994 (suppl. 1).

TREVISI, P.; MELCHIOR, D.; MAZZONI, M. et al. A tryptophanenriched diet improves feed intake and growth performance of susceptible weanling pigs orally challenged with Escherichia coli K88. Journal of Animal Science, v.87, p.148-156, 2009.

WILLIAMS, N.H.; STAHLY, T.S.; ZIMMERMAN, D.R. Effect of chronic immune system activation on the rate, efficiency, and composition of growth and lysine needs of pigs fed from 6 to $27 \mathrm{~kg}$. Journal of Animal Science, v.75, p.2463-2471, 1997.

UNIVERSIDADE FEDERAL DE VIÇOSA - UFV. Manual de utilização do programa SAEG (Sistemas de Análises Estáticas e Genéticas). Viçosa, MG, 1997. 150p.

UNRUH, J.A.; FRIESEN, K.G.; STUEWE, S.R. The influence of genotype, sex, and dietary lysine on pork sbprimal cut yields and carcass quality of pigs fed to either 104 or 127 kilograms. Journal of Animal Science, v.74, p.1274-1283, 1996.

VAN LUNEN, T.A.; COLE, D.J.A. The effect of lysine/digestible energy ratio on growth performance and nitrogen deposition of hibrid boars, gilts and castrated male pigs. Journal of Animal Science, v.63, p.465-475, 1996.

YEN, H.T.; COLE, D.J.A.; LEWIS, D. Amino acid requirements of growing pigs. 7 . The response of pigs from 25 to $55 \mathrm{~kg}$ live weight to dietary ideal protein. Animal Production, v.43, p.141-154, 1986. 